Вставка А

\title{
Олег Хома
}

\section{APERCEVOIR, PERCEPTIO I PERCEPTION: ДЕКАРТ ПЕРЕД ПРОБЛЕМОЮ САМОПЕРЕКЛАДУ}

Подібність термінів apercevoir/percevoir, aperception/perception, a також perceptio/perception не повинна вводити українського читача в оману.

Хоча дієслово apercevoir зустрічається у фр. текстах з XI століття (percevoir - 3 XII-го), однак іменник aperception - це штучний термін, створений Ляйбніцем на поч. XVIII ст. (див. вище $\S$ II); тому його не було в лексиконі Декарта і французьких перекладачів латинських Картезієвих текстів. Традиційне значення дієслова apercevoir 4-те вид. Словника Франиузької академії (1762) і ще навіть Е. Літре (Littré, 1872) формулюють як commencer à voir, букв. «починати бачити», тобто - «помічати». У французьких текстах Декарта і авторизованих французьких перекладах його латинських творів apercevoir вживається саме у цьому значенні.

Іменник perception, зафіксований у текстах ще XII ст., попри зовнішню подібність, не був відповідником apercevoir і традиційно (як і відповідне йому дієслово percevoir) мав цілком чітке значення «отримання, стягнення» (прав, грошей, плодів праці, податків), як свідчить перше видання Словника Франиузької академії (1694). Втім, враховуючи досвід започаткованого Декартом слововжитку, цей словник наводить вже й суто філософський сенс терміна: l'action par laquelle les objets des sens sont apperceus, sont sentis «дія, через яку помічаються, відчуваються об’єкти почуттів».

Тож лексичні труднощі Декарта, що прагнув частково змінити французький філософський терміновжиток середини XVII ст., цілком зрозумілі: якщо лат. perceptio традиційно означало й «отримання, збирання, збір», i «розуміння, осягнення, пізнання, сприйняття», то його, здавалось би, найприродніший фр. відповідник perception не мав цього абстрактного значення. Ще у 1694 р. (і принаймні до кінця XIX ст.!) воно позначалось у французьких словниках як суто філософське, тобто відсутнє у повсякденній мові, натомість Декарт прагнув писати свої французькі твори так, що вони були зрозумілими освіченим читачам зі «здоровим глуздом», бажано не пов'язаним із академічними колами. Цим зумовлена позірна непослідовність французьких перекладів його латинських творів, коли perceptio вкрай рідко перекладається як perception: до нового слововжитку мали звикнути не лише публіка, а й сам автор та перекладачі. Щоб оцінити масштаб цієї новації, український читач може спробувати застосувати іменник «стягнення» (i, відповідно, дієслово «стягувати») не у фіскальній сфері, а для позначення тих психологічних феноменів, які ми зазвичай відтворюємо через терміни «сприйняття»/«сприймати». Він одразу побачить, наскільки невдало і неприродно лат. perceptio veritatis (Августин, Cnовiдb VIII, V, 11) відтворюватиме фраза «стягнення (чи навіть отримання) істини». Певна річ, Декартова ситуація не була настільки гострою, адже змістовний розрив між percep- 
tio/perception частково компенсувався майже цілковитою подібністю самих слів, але й за таких умов процес звикання основної маси французьких мовців до perception у сенсі «сприйняття» розтягнувся на два 3 половиною століття!

Відтак дієслово apercevoir у Декарта ми скрізь перекладаємо як «помічати», оскільки воно має суто побутове значення, ніяк не пов'язане з «аперцепцією», що вперше з'явиться лише за вісім десятиліть у Ляйбніца (1714). Показово, що Ляйбніц в першому викладі своєї доктрини, у Дискурсї про метафізику (1685-1686), ще цілком вдовольняэться Декартовими лексичними ресурсами, коли йдеться про проблематику apercevoir/perception.

Надання абстрактного значення латинського perceptio французькому термінові perception через увідповіднення його до дієслова apercevoir i, таким чином, залучення останнього у філософський дискурс, є істотною Декартовою новацією. (Втім, Декарт не наважився вжити у новому сенсі ще й дієслово percevoir; у Пристрастях душі дія perception завжди виражається лише дієсловом apercevoir.) М. Фішан вельми вдало описує динаміку цього процесу, аналізуючи присутність perception у Декартових французьких текстах різних років: відсутній у ранніх творах (1630-1637), він вперше епізодично з'являється у авторизованих французьких перекладах Медитацій і Принuуипів, що вийшли друком 1647 року, а згодом повноправно входить у лексикон Пристрастей душі (1649).

\section{БІБЛІОГРАФІЯ}

AUGUSTIN, Saint Les Confessions / introd. et notes par Joseph Trabucco; texte latin et trad. fr., Garnier frères, 1938, 2 vol.

DESCARTES Rene, Euvres, éd. C. Adam et P. Tannery, 11 vol., reéd. Vrin, 1996.

LEIBNIZ Gottfried Wilhelm, Discours de métaphysique, suivi de Monadologie et autres textes, éd. établie, présentée et annotée par Michel Fichant, Gallimard, 2004.

\section{ДОВІДКОВА ЛІТЕРАТУРА}

Dictionnaire de l'Académie française, 4ème édition, Vve de B. Brunet, 1762, 2 vol.

Le dictionnaire de l'Académie française, J. B. Coignard, 1694, 2 t. en 1 vol.

LITTRÉ Emile, Le dictionnaire de la langue française, Hachette, 1863-1872, 2 t. en 4 vol.

\section{Oleg Khoma}

\section{Apercevoir, perceptio and perception: Descartes and the problem of self-translation}

The paper explains the contextual discrepancy between the grammatically related terms apercevoir/percevoir/percipere, aperception/perception, as well as perceptio/perception in French philosophical vocabulary of the mid-17th century. Bilingual Descartes's philosophy is a peculiar testing area for changing the traditional meanings of these terms. In the Latin texts of Cartesius the word percipere and the noun perceptio denote, correspondingly, the process and the result of perception. However, the difficulty appeared during the preparation of the French texts of Descartes's Latin works, since percevoir/perception, the natural French correspondents for percipere/perceptio, did not have the epistemological connotations and denoted «getting, collecting» (money, taxes etc.). Therefore Descartes chose for situational correspon- 
dents of percipere a number of French verbs with similar meaning (concevoir, connaitre etc), sometimes apercevoir («notice») and never percevoir. For the noun perceptio he selected notion, connaissance and very rarely perception in the new epistemological meaning «perception», which was pretty difficult to comprehend for the French-speaking milieu of those days. As to the term aperception, it is totally artificial, and it was suggested by Leibniz in 1714 in order to denote the act of conscious perception.

Oleg Khoma, Doctor of sciences in philosophy, Professor, Head of the Department of Philosophy of Vinnytsia National Technical University

Олег Хома, доктор філософських наук, професор, завідувач кафедри філософії Вінницького національного технічного університету

Олег Хома, доктор философских наук, профессор, заведующий кафедрой философии Винницкого национального технического университета 